\title{
A Német Urológus Társaság első kongresszusának budapesti sajtója
}

1907 a k. und k. boldog évei közé tartozott. Ebben az évben lett Ausztriában általános a választójog. Hágában megtartották a 2. Békekonferenciát; nem sok eredménnyel. A Hymen-hírek között olvashatjuk, hogy gróf Széchenyi Mária és Windischgrätz herceg házasságot kötöttek. Az 1907. október 2. és 5. között tartott kongresszust Bécsben szervezték meg. Három magyarországi orvosi lap is részletesen tárgyalta a kongresszust. „A szakcongressusok megszokott külsőségeit felülmúló ünnepélyességgel nyiltt meg a fenti társaságnak I. congressusa. Egy főherczeg, a kormány képviselói, a teljes facultás, az orvosegyesület, nagy ünnepi közönség, igen sokan a birodalomból, néhány franczia, amerikai, holland és mi magyarok igen szép számban, Ausztriából pedig mindenki." A fenti sorokkal kezdi beszámolóját az Orvosi Hetilap, amelyet TÁRCA rovatában olvashatunk. (Az Orvosi Hetilap a 6. legrégebbi európai orvosi folyóirat, mely alapítása óta, 1857-től folyamatosan megjelenik [1. ábra].)

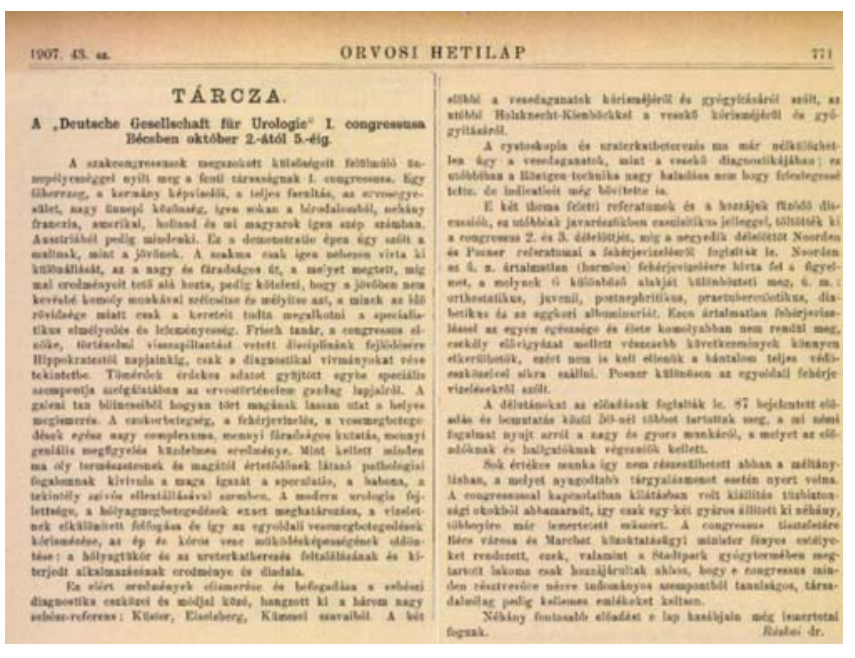

\section{1. ábra: Az Orvosi Hetilap a 6. legrégebbi európal ORVOSI FOLYÓIRAT, AMELY ALAPÍtÁSA ÓTA, 1857-töL \\ FOLYAMATOSAN MEGJELENIK}

A kongresszus elnöke professzor Frisch. A kezdő előadásokat három sebész tartotta: Küsser és Eiselsberg a vesedaganatok diagnosztikájával és terápiájával, Kümmel a vesekövek kezelési lehetőségeivel foglalkozott. A föreferátumok után a technikai újdonságokról volt szó: a cisztoszkópia alkalmazásáról, a húgycső-katéterekről, és mint legfrissebb innovációról, a röntgendiagnosztikáról. Nyilvánvalóan még nem vált szét a nefrológia és az urológia. Posner az albuminuriáról tartott referátumot, sok esetet is ismertettek, összesen 87 bejelentett elöadás volt.

Az orvosi lap hasábjain egy külön kis hirdetés szólt arról, hogy aki a Német Urológus Társaság (DGU) tagja szeretne lenni, annak dr. Háberern Jonathannál kell jelentkezni, három ajánló levelével a megadott címen: Budapest IV. Mária-Valéria utcza 5. A Magyar Urológus Társaság 17 évvel később alakult meg. Az Orvosok Lapja október 24-i számában Weisz Ferenc doktor számol be a kongresszusról (2. ábra). A beszámoló a fent említett békeidőt tükrözi. „Szép, verőfényes napok - valóságos nyári hangulat - volt a lefolyt kongresszusi napokon és a résztvevők nagy száma, meg a különböző országok képviselói szinte internationális jellegúvé tették azt; mert nemcsak Európa minden államából voltak résztvevők, nemcsak Amerika bírt képviselettel, de még a távol keletnek, a mindinkább előretörő sárga fajnak is volt 2 képviselöje, 2 tokiói orvos személyében, kik bár szerényen a háttérben forgolódtak, de azért mindenütt láthatók voltak."
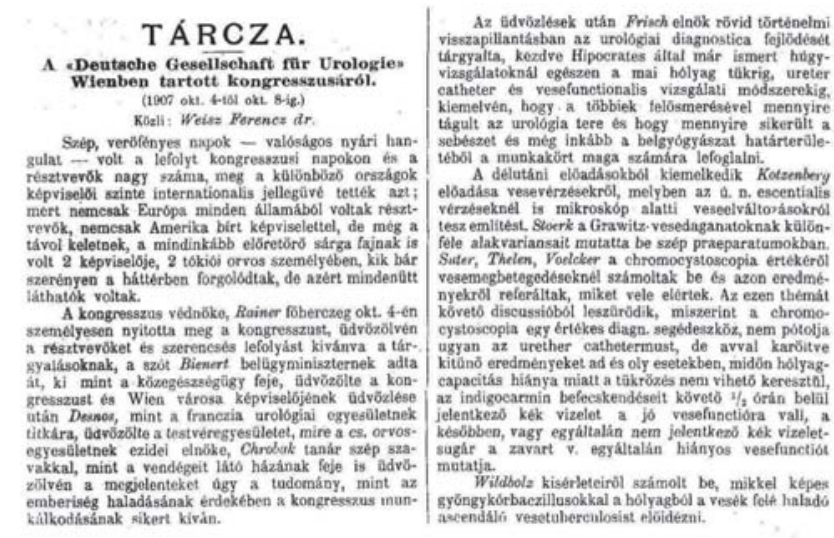

\section{2. Ábra: Az Orvosok Lapja október 24 - I SZÁmÁban} Weisz Ferenc doktor számol be a kongresszusról

A kongresszust Rainer nagyherceg nyitotta meg. Köszöntötte a résztvevőket Bienert belügyminiszter, Desnos, a Francia Urológus Társaság elnöke, Chrobak, a császári orvosegyesület elnöke és Frisch a kongresszus elnöke. Még az első nap elöadást tartott Kotzenbert a vesevérzésről, a híres Voelcker a kromocisztoszkópiáról és a még ismertebb, Győrben született magyar, Zuckerkandl a tbc-röl. A második nap elóadásai között a neves német Casper az anuriáról, Lenk az urémia patológiájáról értekezett. Minden valószínúség szerint a tudósító Weisz adott elő az autovakcina-terápiáról bakteriuriás betegekben. És ez mind már 1907-ben! Nem meglepő, hogy Picker, a gonorrhoeáról tartott nagy referátumot. Weisz megjegyzi, hogy a hosszan tartó viták miatt az idő elhúzódott és több előadást - többek közt a magyar Porosz előadását sem - nem tartottak meg. A harmadik nap eseményei között Weisz megemlíti, hogy minden résztvevő egy szivartárcát és a kongresszusról egy könyvet kapott ajándékba. Az előadások közül a szerző kiemeli Kümmel előadását a krioszkópiáról. A magyar Ráskay a prosztata-hipertrófia etiológiájáról, Lichtenstern a hólyagpapillomákról tartott előadást. Moskowitz a BPH röntgenbesugárzásáról értekezett, amiből nem lett rutin kezelési módszer. 
Az esti fogadás a Stadtpark Coursalonjában volt.

A negyedik napon úgy túnik nefrológiai témák kerültek elötérbe. Noorden ismét az albuminuriáról, Posner a nephritisről tartottak referátumot. Három magyar is szerepelt ismét, Feleky, Emődy és Remete. Az új tiszteletbeli tagok az alábbiak lettek: English (Bécs), Guyon (Párizs), Harrison (London), Israel (Berlin), Küster (Charlottenburg).

Az új levelező tagokat az 1. táblázatban ismertetjük.

1. TÁBLÁZAT: ÚJ LEVELEZŐ TAGOK

$\begin{array}{llll}\text { Albarran } & \text { Párizs } & \text { Meyer } & \text { New York } \\ \text { Beck } & \text { New York } & \text { Pousson } & \text { Bordeaux } \\ \text { Brunni } & \text { Nápoly } & \text { Rafin } & \text { Lyon } \\ \text { Desnos } & \text { Párizs } & \text { Rowsing } & \text { Koppenhága } \\ \text { Fedorov } & \text { Szentpétervár } & \text { Verhoogen } & \text { Brüsszel } \\ \text { Fewick } & \text { London } & \text { Young } & \text { Baltimore }\end{array}$

Létezett egy németnyelvú orvosi lap is 110 évvel ezelőtt: a Pester Medizinisch-Chirurgische Presse (3. ábra). Ennek szeptember 29-i számában néhány különlegességről is olvashatunk a kongresszussal kapcsolatban. A kongresszusi résztvevők számára kórház-, illetve urológiai osztály-látogatásokat is terveztek. Így az Allgemeine Poliklinikba (Mariannengasse 10), Frisch osztályára (Rudolfiner Haus, Billrothgasse 78) és az Izraelita Kórházba a Währinger Gürtel 98-ba. Ugyancsak Zuckerkandl osztályára; a címét nem közölték. Két nappal később szintén kora reggel az I. és II.

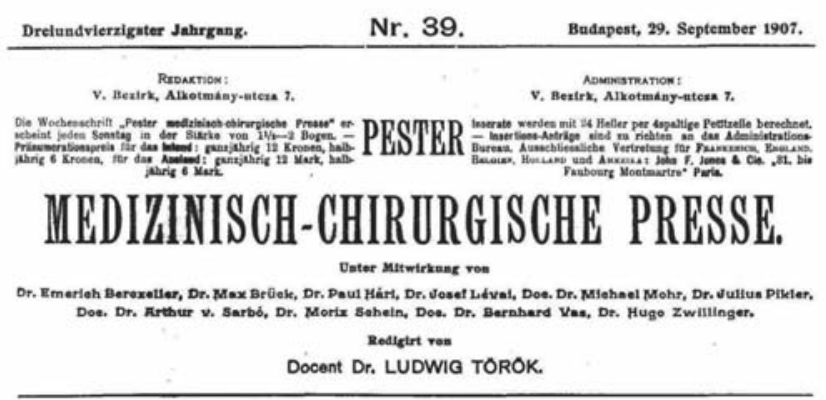

3. Ábra: LÉtezett egy németnyelvÜ ORVOSI LAP IS 110 évvel ezelőtt: a Pester Medizinisch-Chirurgische Presse

sz. Sebészeti Klinikára is szerveztek látogatást. Mindkettő az Alsel Str. 4-ben volt.

A hölgyekről sem feledkeztek meg. Kéretnek a hölgyek minden ünnepi eseményen részt venni. Egy kirándulást is szerveztek a Hochschneebergre.

Rövid beszámolómból látszik, hogy a negyven éve fennálló monarchia és a körülbelül ugyanennyi idős Németország nyelvileg, kulturálisan, tudományosan egy nagy egységet képviselt. A német társaság kongresszusát Bécsben tartja, az Osztrák Urológus Társasággal karöltve, amelyet egyébként egy magyar alapított (Zuckerkandl). Ennek nyomait láthattuk 20-30 éve az osztrák-magyar közös kongresszusokon és a kiterjedt, széles magyar-német urológiai kapcsolatokban is.

Legyen ez így tovább is!

Romics Imre dr.

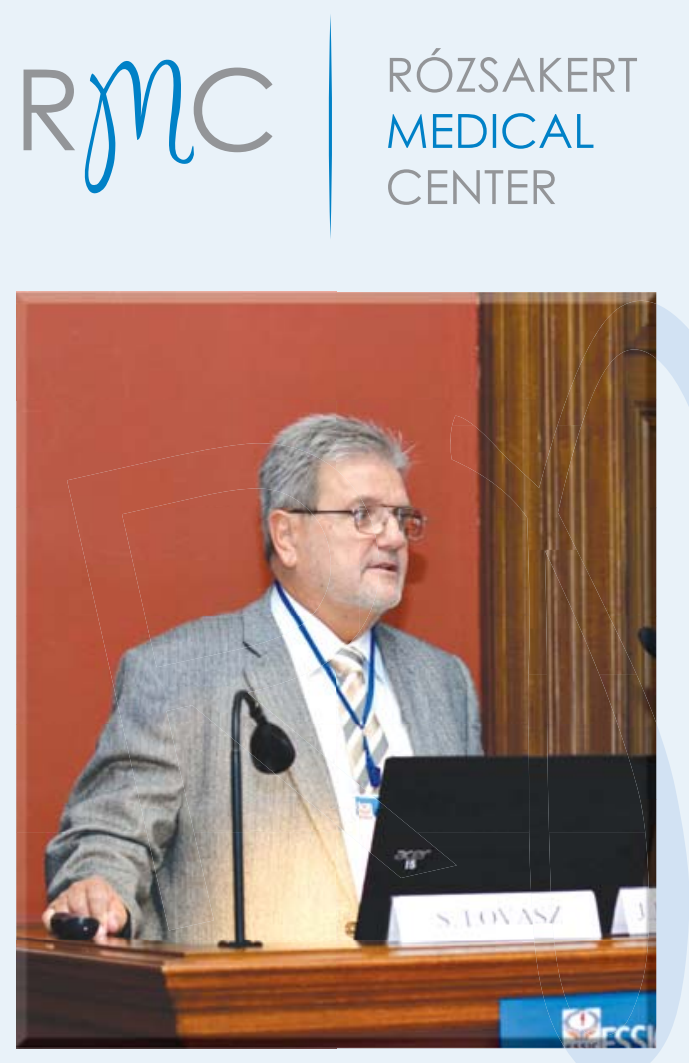

\section{Urológus szakorvosokat keres a Rózsakert Medical Center}

Második kerületi magánklinikánkra olyan urológusok jelentkezését várjuk, akik elmélyülnének a hólyagfájdalom szindróma kezelésében és kutatásában. A hólyagfájdalom szindróma (interstitialis cystitis) egy rendkívül kellemetlen tünetekkel járó betegség, amelyet csak az esetek 1-2\%ában tudnak diagnosztizálni.

A Rózsakert Medical Centerben dr. Lovász Sándor urológus vezetésével kiemelten foglalkozunk e betegség gyógyításával és a legújabb gyógymódok kidolgozásával. Megnövekedett páciensforgalmunk ellátásához keresünk urológus kollégákat. Amennyiben érdekli az általunk nyújtott lehetőség, küldje el önéletrajzát nekünk.

Jelentkezését az alábbi e-mail címre várjuk: kiss.aniko@rmc.hu 